\title{
Knowledge of the Problem of Fuel Poverty Among Local Government Authorities: In The Aspect of Local Energy Security
}

\author{
Katarzyna ŚWIERSZCZ, Tadeusz SZCZUREK, Szymon MITKOW, \\ Jerzy ZALEWSKI and Bogdan ĆWIK
}

Military University of Technology in Warsaw, Warsaw, Poland

Received date: 6 February 2019; Accepted date: 19 April 2019; Published date: 26 June 2019

Academic Editor: Carmen Nadia Ciocoiu

Copyright C 2019. Katarzyna ŚWIERSZCZ, Tadeusz SZCZUREK, Szymon MITKOW, Jerzy ZALEWSKI and Bogdan ĆWIK. Distributed under Creative Commons CC-BY 4.0

\begin{abstract}
The constant increase in energy demand among local communities, which is a natural consequence of the desire to improve the quality of life, as well as the ongoing economic growth and civilization progress, breeds a worrying problem of fuel poverty, which remains at a persistently high level. This phenomenon is particularly experienced by the inhabitants of farms, not only poor ones but also those more affluent. Research shows that this problem is not perceived as one of the aspects of fuel poverty, which determines the level of energy security in the local dimension. What's more, this phenomenon is unknown to many local authorities or has a low priority. There are also local governments, which notice this problem, but in the absence of appropriate definitions of fuel poverty and the lack of appropriate tools to study this phenomenon, they resolve it intuitively. In the article, the authors, therefore, focus on three objectives. The first is the attempt to define the concept of fuel poverty as an indicator of energy security at the local level. The second is to examine the degree of knowledge of fuel poverty among local authorities in selected Polish provinces. The third is to show ways to counteract the phenomenon of fuel poverty among the inhabitants of farms. The research problem posed in the article is of a theoretical and empirical nature. The applied research methods are: analysis, definition, synthesis, generalization and inference as well as quantitative and qualitative research methods. The research was conducted among farms in 438 counties in the following provinces: Masovian, Subcarpathian, Greater Poland and West Pomeranian in Poland. The topic of the article may help in the pragmatic dimension to develop an effective strategy of counteracting fuel poverty, thus strengthening local energy security, which will be able to be applied by local government units in the country.
\end{abstract}

Keywords: heat energy poverty, energy security, combating heat energy poverty

Cite this Article as: Katarzyna ŚWIERSZCZ, Tadeusz SZCZUREK, Szymon MITKOW, Jerzy ZALEWSKI and Bogdan ĆWIK (2019)," Knowledge of the Problem of Fuel Poverty Among Local Government Authorities: In The Aspect of Local Energy Security" Journal of Eastern Europe Research in Business and Economics Vol. 2019 (2019), Article ID 780276, DOI: 10.5171/2019.780276 


\section{Introduction}

Poverty in the general sense of the word is widely discussed in Poland. Issues related to it are a matter of concern for various branches of policy, both social and economic, at the national and local level. However, the specific dimension of this phenomenon of heat energy poverty in many households is little known, and thus poorly researched and described. Its features manifest themselves in a multidimensional way and often lead to various destructions, both social and economic. At the same time, they also express the level and quality of energy security of households. Numerous surveys conducted among Local Government Bodies throughout the country also show that this problem is a foreign one for many local authorities. This is due to the lack of awareness of this problem as energy poverty - despite the fact that this phenomenon is becoming more and more a priori experience both in the local dimension (in the territories of many Polish municipalities), as well as in the regional dimension, and in the whole country. Although there are local authorities for which the problem is recognised, in the absence of appropriate definitions and tools, it is studied and solved in an intuitive way. The above situation shows that: municipalities need a better method of estimation/calculation of the scale of energy poverty in their area, which would be as precise as the calculation of the scale of economic poverty. To this end, it is necessary to adopt a definition of heat energy poverty that is easy for municipalities to apply.

The issue of heat energy poverty seems to be a low priority for municipalities (even lower than in the case of economic poverty). As a result, they do not monitor this phenomenon, nor do they draw up special plans to reduce its scale. By the same token, they also do not increase the level of energy security in the local dimension. The actions taken by the municipality practically boil down to the use of standard social policy instruments.

The importance of the topic is, therefore, due to a number of issues. The first is to gain as much knowledge as possible about the phenomenon of heat energy poverty experienced on a daily basis by many households in the municipalities; the second is to understand the essence of heat energy poverty. The third is the identification and recognition of the main factors determining it. Finally, the fourth is to provide and enable the development of effective and comprehensive instruments to combat heat energy poverty.

\section{The concept of heat energy poverty as an indicator of energy security - literature analysis}

Heat poverty, which is an element of fuel poverty (or energy poverty) in the general sense of the word, is a disturbing phenomenon of social life today, experienced in Poland, as well as in other countries (little and highly developed) of the European Union and even the world. This phenomenon is not something new in social experience, however, only nowadays has it started to be conceptualized and studied as an autonomous problem. Due to the extent and importance of the problem, the dilemma of heat energy poverty is particularly evident in the problem. This concept, although it is not directly articulated in the literature of the subject, both domestic and foreign, its aspects and its features can be found in it. They are particularly visible in the statements of experts in the subject of energy poverty, the conceptual scope of which is much broader, because it also covers electricity.

Referring to these researchers, it is worth noticing the definition of D. Owczarek and A. Miazga (2015), in which, in addition to the discussed issue of energy poverty in the broad sense, one can find aspects

Katarzyna ŚWIERSZCZ, Tadeusz SZCZUREK, Szymon MITKOW, Jerzy ZALEWSKI and Bogdan ĆWIK (2019), Journal of Eastern Europe Research in Business and Economics,

DOI: $10.5171 / 2019.780276$ 
related to heat poverty. They are visible in the situation when, as the authors say, household dwellers experience two-fold difficulties in the dimension of energy needs. The first one is the problems in meeting the basic needs of heat energy, which is visible in the inability to maintain a specific standard of heat allowing to adequately meet the basic needs of the biological and social functioning of the household inhabitants. At this point, it should be emphasized that the statutory standard of heat in Polish flats, which allows experiencing the feeling of comfort, is the temperature of $21^{\circ} \mathrm{C}$ (cf. DEEC 2014), and for other occupied premises it is $18^{\circ} \mathrm{C}$. The second difficulty is the problem of purchasing this energy at a reasonable price in the place of residence (Świerszcz 2017; Teller-Elsberg, Sovacool, Smith, and Laine 2016). Elements of heat energy poverty in households can also be seen in the definition of energy poverty by $S$. Bouzarovski and S. Petrova (2015) and J. Rutkowski, K. Sałach and other coauthors (2018), who, in the discussed issue, point to such phenomena as: difficulties in meeting energy needs for heating the apartment and free use of hot water by residents of houses. The source of these difficulties are usually low financial income and the character of the apartment. A significant complement to the understanding of the phenomenon of heat poverty can be found in the definition of energy poverty developed in the research work by C. Sánchez-Guevar Sánchez, A. Mavrogianni and F. J. Neil González (2017), as well as A. Stępniak and A. Tomaszewska (2014). The authors draw attention to such aspects as: the problem of maintaining a comfortable temperature of heat by members of households, lack of funds to pay heating bills, or difficulties in repairing a nonfunctioning heating system or appliance; the inability to buy and install a new system or appliance, and finally, the inability to adequately modernize the heating system in place. Another very important element defining the phenomenon of heat poverty in the discussed problem of energy poverty is the constant experience by the inhabitants not only of cold, but even cold and the related humidity of the air and walls, as well as fungus. The consequence of such conditions are frequent diseases of the residents, as well as mental discomfort. Explaining the essence of heat poverty, this phenomenon can also be referred to a situation in which households experience a lack of access to the socially and materially necessary level of energy services at home. Their lack of satisfaction is connected with material deprivation and social exclusion. Such a way of presenting the problem indicates that it is not only about treating a human being as an organism, but also as a social being, whose needs are conditioned by the group in which they live (Świerszcz and Grenda 1018; Bouzarowski 2018). Poor in heat energy are therefore those households which are in a difficult economic situation and at the same time are above average burdened with energy costs. This situation may lead, on the one hand, to problems with heating or cooking and, on the other hand, to limiting expenditure on other needs, including basic needs such as heat energy (Świerszcz 2018a; Świerszcz and Ćwik 2017; Bakirtas and Gokce Akpolat 2018). Also noteworthy is the definition of $\mathrm{B}$. Boardman (2012), which also contains the elements relating to heat poverty. They refer to the situation in which households are forced to spend more than $10 \%$ of their income in order to be able to obtain a sufficient level of heat in heating the dwelling.

On the basis of the quoted attempts to define heat energy poverty, it can be said that this phenomenon in Polish households, of which there are approx. 13.3 million - according to the Household Budget Survey conducted by the Central

Katarzyna ŚWIERSZCZ, Tadeusz SZCZUREK, Szymon MITKOW, Jerzy ZALEWSKI and Bogdan ĆWIK (2019), Journal of Eastern Europe Research in Business and Economics,

DOI: $10.5171 / 2019.780276$ 
Statistical Office (GUS 2017) - in 2017 concerned $9.6 \%$ of households, which constitutes 1.3 million houses, i.e. 4.5 million people. This poverty was calculated on the basis of an objective LIHC (Low Income High Costs) measure, which takes as energy poverty a situation in which households spend more than $10 \%$ of their income on maintaining a sufficient level of heat. This situation was visible in all provinces of Poland, however, with varying degrees of intensity. This state of affairs was most experienced in the following provinces: Podkarpackie - $17 \%$ of households, Podlaskie - $17 \%$ of households, Opolskie $15 \%$ of households, Lubelskie - $14 \%$ of households and Świętokrzyskie - 12\% of households. To a slightly lesser extent, this situation was experienced in the following provinces: Dolnośląskie - 7\% of households, Pomorskie - $7 \%$ of households, Mazowieckie - 7\% of households and Śląskie - 6\% of households.

The characteristics of energy poverty in the rural-urban context, taking into account the high energy costs incurred by households in relation to their income i.e. on the basis of the objective LIHC measure - make it easy to see that this phenomenon is visible mainly among households living in rural areas. It amounts to about $62 \%$ in relation to a city where poverty is about $20 \%$. What characterises the poor rural population, apart from their low incomes, are their old and small houses, outdated thermal insulation, heating with old coal-fired stoves in poor technical condition, as well as the inability to carry out thorough renovations on their own, including thermomodernization. Taking into account the development criterion, the most energy poverty is experienced by residents of single-family houses - as much as $65 \%$ of households, followed by residents of blocks of flats - $16 \%$ and tenement houses - $16 \%$. Taking into account the occupational criterion, energy poverty is visible mainly among: manual workers - 29\%; pensioners - $21 \%$ and farmers - 14\% (GUS 2017).

Speaking of heat energy poverty among households, it can be seen that this phenomenon, due to its prevalence and its various consequences, may constitute one of the important indicators of local energy security. It can also be a test of its level and quality. This security, as D. Yergin (2006) notes, in fact, is supposed to meet two conditions. The first is to ensure an adequate and reliable level of energy supply for its customers, which, in this case, are households. The second is selling energy at reasonable prices, which will not only endanger other existential and living needs, but also allow for their free realization and constant development. In a similar tone, the essence of energy security is defined by the Polish Ministry of Economy in the "Energy Policy of Poland until 2030" (2009). In this document, the essence of energy security is understood as the ability to ensure stable fuel and energy supplies at a level that guarantees, among other things, the satisfaction of social needs at prices accepted by this society. This definition is complemented by an interpretation of energy security in the context of the International Energy Agency (IEA) (2019). In its opinion, energy security - from a practical point of view - should be seen as a problem of risk management, i.e. the ability to reduce the risk and consequences of disruptions to a level that is acceptable to its users (i.e. households). The definition of energy security proposed by the Polish Industrial Lobby (Soroka 2015; Świerszcz 2018b) is also noteworthy. In this definition, the essence of energy security is recognised in the continuity and reliability of energy supply to, among others, individual consumers, such as households, at costs and prices that are the lowest and most competitive, while maintaining environmental standards in generation, transmission and consumption. The 
essence of energy security is also the availability of energy in appropriate quantities, at the right time and in the right place (while meeting appropriate quality and ecological parameters, consistent with the principles of sustainable development), so that it is possible to meet the basic existential and living needs of households, not only for the nearest future, but also for a longer period of time (Świerszcz and Grenda 2018; Mirjana, Sanja and Dejan 2017). The above examples of understanding of the essence of energy security of households indicate three key dimensions of this concept. These are social, economic and ecological dimensions. Meeting these dimensions, in the context of household needs, is a necessary condition to ensure a sense of energy security in the local context. Otherwise, the failure of even one of them has serious consequences for the lives of households, the form of which is the deprivation of heat energy poverty.

\section{Awareness of the phenomenon of heat energy poverty in households in the perception of local government}

Surveys conducted among local government bodies in Poland, on the degree of their awareness of the phenomenon of heat energy poverty in households in the area managed by them, provide a lot of important and thoughtprovoking information. It turns out that the situation of heat energy poverty of the inhabitants is little known, and thus examined and described in local government documents. This is indicated by the lack of response in the survey on the subject under study or replies informing about the lack of discernment and lack of data in this subject. This is also evidenced by the numerous direct interviews conducted in the community of local government officials, whose statements are sometimes very meaningful in terms of content.
Among the 438 surveyed municipalities, the question: Are the Territorial SelfGovernment Units (TSU), which are responsible for organizing the heat market and helping the poorest residents, aware of the existence of heat energy poverty - was answered by as much as $73 \%$ that the problem is not researched in their area; $17 \%$ stated no data on the subject; and only $10 \%$ stated that they diagnosed the phenomenon.

According to further studies, this problem is estimated on the basis of various forms of support provided by public and nonpublic institutions, such as: social assistance and welfare - 34\%; energy allowance - 28\%; housing allowance $11 \%$; subsidies (as support for the payment of energy bills arrears) - 9\%; "Prepaid card" - 7\%; energy discounts 5\%; in-kind assistance - 4\%; and other information, e.g. advice on energy saving (improving energy efficiency) and the use of energy allowances - $2 \%$.

According to the data available to the selfgovernment, it turns out that among the persons benefiting from this type of aid are: elderly people - 39\%; families with many children - $23 \%$; people living in buildings requiring energy efficiency improvement - 21\%; people living in municipal blocks - 12\%; people living in old buildings - 12\%; people living in single-family houses - 6\%; young and single people - 5\%; and young married couples - $2 \%$. Studies have also shown the main reason that makes it difficult to diagnose heat energy poverty among residents. It turns out that this cause has a twofold source. The first source lies in the local community itself, which is expressed in the lack of social activity, i.e. lack of interest on the part of people threatened by this phenomenon. The reason for this should be seen first of all in: low motivation to apply for the energy allowance due to the low level of funding granted, high level of bureaucracy

Katarzyna ŚWIERSZCZ, Tadeusz SZCZUREK, Szymon MITKOW, Jerzy ZALEWSKI and Bogdan ĆWIK (2019), Journal of Eastern Europe Research in Business and Economics,

DOI: $10.5171 / 2019.780276$ 
involved in submitting this application, the lack of relevant provisions and low public awareness. The second source is the local government, which is expressed in: no need to conduct research on the occurrence of this phenomenon in the municipality, lack of appropriate amount of finance and qualified staff in this problem area, lack of access to data, as well as lack of appropriate tools (Świerszcz 2019a; Petrova 2016).

Studies also show that in the last ten years, the majority of local governments, approx. 65\% have undertaken exemplary investments in energy efficiency to reduce the energy consumption of people at risk of heat poverty, as well as preventive measures to raise living standards. These activities consisted of: modernization of street lighting - 18\%; replacement of bulbs in the building with energy-saving ones - 15\%; education (how to effectively use what we have) $14 \%$; reduction of energy demand - 5\%; thermomodernization (insulation) of buildings - $12 \%$; replacement of windows in buildings - $10 \%$; installation of modern central heating - 9\%; construction of lowenergy social buildings - 7\%; modernization of heating systems - 4\%; modernization of energy transmission system - 3.5\%; improvement of energy consumption efficiency at the consumer $2 \%$; investment in renewable energy sources (RES) - $0.5 \%$.

For these measures aimed at improving the quality of life of residents in terms of heating, local governments allocated funds in the following amounts: PLN 1-5 million (68\%); PLN 5-10 million (24\%) and over PLN 10 million (8\%). The degree of satisfaction among residents with the actions taken by local government was mostly average - 41\%. The remaining level of satisfaction was: good - 34\%; weak - $17 \%$, dissatisfaction - $8 \%$ and very good - 2\%. The study also noted proposals for solutions recommended by Local Government Units as additional or more effective than the existing tools, which are used to solve the problem of heat energy poverty. Among them, the following are proposed: revolving fund; grants from national funds; grants from European Union funds; redemption of liabilities; construction of energy-efficient municipal housing; improvement of energy efficiency in residential buildings; implementation of programmes to connect housing (not only municipal) to the local heating network; investment in renewable energy sources; comprehensive solutions in the form of grants to NGOs that will carry out the energy efficiency investment process and educational and advisory activities; modification of the white certificate system to exempt energy companies from participating in a tender for white certificates if they cover part of the costs of energy efficiency investments in energy-poor households (e.g. thermomodernization, replacement of appliances with energy-efficient ones, etc.), motivating energy companies to act in favour of energy-poor consumers (in exchange for receiving white certificates in modified form and many others). In order for these actions to be possible, according to the local government, cooperation is needed with entities such as: qualified workers; universities involved in energy efficiency projects; companies involved in energy efficiency, e.g. energy companies, distributors, energy suppliers, companies providing energy effect services such as Energy Service Company (ESCO), Municipal Social Welfare Centre (MOPS), Communal Social Welfare Centre (GOPS); institutions involved in providing financial sources for the implementation of energy efficiency projects, e.g. Regional Operational Programme (ROP), National Fund for Environmental Protection and Water Management (NFOŚiGW); social welfare and many others for which the problem of heat energy poverty in households is important. 
Important information in the conducted surveys is also provided by answers to the question about the possibility of solving the problems of heat energy poverty through the implementation of cooperation with other municipalities, at the county, provincial or national level. It turns out that the majority of selfgovernments declare interest in such cooperation, however, from the practical point of view, as their own experience shows, such cooperation is relatively ineffective. The main reason for the low effectiveness of this cooperation are the financial problems of individual communes and the lack of suitably qualified personnel who could take decisive action to eliminate, or at least reduce, the phenomenon of heat energy poverty among household inhabitants in a competent, permanent and comprehensive manner.

\section{Measures to combat heat energy poverty in households}

Knowing the causes of the phenomenon of heat energy poverty among household members and its consequences in their daily lives, it would seem appropriate to draw attention to the question of proposals for instruments to deal with this phenomenon, in three dimensions: prevention, limiting and reduction. They are referred to in the "Energy Policy of Poland", proposed until 2030. (Policy 2030) and 2050 (Project 2050). This policy does not speak directly, in a formal way, about the fight against heat energy poverty, but because of the importance of the good that is energy to meet basic human needs, both physiological and social, it proposes or even points to appropriate instruments and directions of action which, in their natural consequence, have an impact on the reduction of this type of energy poverty. At this point, it should be stressed that this policy is, to a significant extent, a response to the European Union's common energy policy, as well as its implementation - particularly in its three main objectives called ' 3 x 20': a 20\% reduction in greenhouse gas emissions; a $20 \%$ increase in the share of renewable energy sources in energy use and a $20 \%$ reduction in energy consumption by improving energy efficiency. Poland's energy policy - inscribing them into national legislation - undertakes to implement these actions, taking into account, among others: protection of the interests of consumers, energy resources held, energy security of the country and technological conditions of energy production and transmission (Project 2050; Policy 2030; Energy Saving 2014). These actions, in their natural consequence, will influence the degree to which the phenomenon of heat energy poverty is reduced.

Priority actions include, among others: the above mentioned improvement of energy efficiency, including energy efficiency in the construction industry, the whole housing sector, as well as households; development of the use of renewable energy sources, statutory activities of local government units, taking into account the priorities of the state's energy policy, including the use of public-private partnership (PPP); prioritised spatial planning, ensuring the implementation of energy policy priorities, heat supply plans and development plans of energy companies, as well as public support, including European funds, to implement energy efficiency measures (Hovard 2015; Hilbert and Werner 2016, Szczurek and Bryczek-Wróbel 2017). Educational activities in the field of energy saving knowledge, shaping attitudes in this direction, as well as conducting a promotional and awareness campaign on the importance of effective use of energy (Crémieux 2014; Roberts 2008; Świerszcz and Grenda 2018a) are also important

Katarzyna ŚWIERSZCZ, Tadeusz SZCZUREK, Szymon MITKOW, Jerzy ZALEWSKI and Bogdan ĆWIK (2019), Journal of Eastern Europe Research in Business and Economics,

DOI: $10.5171 / 2019.780276$ 
(Crémieux 2014; Roberts 2008, Włodarczyk 2018).

When taking measures to reduce heat poverty using appropriate instruments, it should be noted that due to the complexity of the problem of heat poverty, they affect or require radical intervention in three areas: household incomes, energy prices, energy efficiency of buildings (Świerszcz 2016a; Pye and Dobbins 2015; Zalewski 2015). In Poland, these areas are covered by three public policies in the national dimension, which are implemented respectively by three ministries: social policy - Ministry of Family, Labour and Social Policy; housing policy - Ministry of Infrastructure and Construction (which is complemented by environmental policy - Ministry of Environment) and energy policy Ministry of Energy and Energy Regulatory Office (ERO). These policies primarily set the framework for concrete actions, while ministries pave the way for their implementation. It should be stressed here, however, that in accordance with the principle of subsidiarity, efficient and effective implementation of these policies also depends, to a large extent, on the involvement of local government units that are closest to society and their everyday problems, including energy poverty (Świerszcz 2019b; Szpor and Lis 2016).

Among the social policy instruments introduced by the ministry responsible for it, there are: housing allowance, energy allowance, special purpose allowance and energy flat-rate price. The instruments of housing policy and its complementary policy in the fight against heat energy poverty are: thermomodernization bonus; exemption from real estate tax for buildings where façade renovation has been carried out; subsidies and preferential credits under the Air Protection Programme; Operational Programme Infrastructure and Environment (OPI\&E) (investment priority), as well as Regional Operational Programmes supporting projects investing in deep thermomodernization of buildings (multi-family buildings); subsidies for loans for the construction of energy-efficient houses or purchase of houses (flats) from the NFOŚiGW programme; "KAWKA" programme, aimed at liquidation of low emission, e.g. elimination of household coal-fired stoves, as well as promoting the use of alternative and energy-efficient solutions in households, the "RYŚ" programme to reduce final energy consumption and $\mathrm{CO} 2$ emissions through the use of thermal upgrading and modern solutions in energy consumption, including renewable energy sources. The third area of mechanisms aimed at raising public awareness and changing their attitudes in the field of energy use concerns such instruments as a nationwide system of advisory support for the public sector, housing and enterprises in the field of energy efficiency and renewable energy sources, as well as promotion and education programmes in the field of energy efficiency, for example "Time to save energy" (Ministry of Economy), "Turn off the power. Turn on saving" (Ministry of the Environment) and "You have a choice" (Energy Regulatory Authority), raising awareness and promoting energy efficiency opportunities (Świerszcz and Grenda 2018b; Scarpellini, Sanz Hernández, Llera-Sastresa, Aranda and López Rodríguez 2017).

Given the need to involve the three dimensions of policies (areas) in the fight against heat poverty, it is not insignificant, as can be seen, that the choice of instruments is also appropriate. Modification of existing instruments is less costly, both financially and organisationally, and involves less uncertainty. Reducing heat poverty also requires taking into account modified costs and newly introduced instruments. In view of the two recently introduced 
and consistently implemented priority social policy programmes, namely: " 500 plus" and "Housing plus" - it seems to be an easier task to create solutions that will not burden households' budgets at least to such a large extent. They can be based on better addressing or replacing existing mechanisms with new ones (Szpor and Lis 2016).

\section{Conclusion}

On the basis of questionnaires addressed to Territorial Self-Government Units in municipalities, it can be unequivocally stated that the situation of heat energy poverty is poorly recognized (at an insufficient level). It can even be said that, in most cases, the situation is completely unknown. This is evidenced by the results of the survey, as well as by the statements of municipality officials during telephone conversations. It is worth noting that information obtained from a survey of local governments indicates that poor households pay their energy bills by giving up other expenses - which means that the real scale of the problem of energy poverty remains unknown. Therefore, the problem of energy poverty is to a large extent perceived by the local governments, first of all, intuitively.

Due to the lack of an official definition of the unambiguous notion of heat poverty, developed at national level, and the lack of obligation to monitor this phenomenon (problem) in the municipality - this issue is most often dealt with by social welfare. This institution, although it sees the problem of heat energy poverty as an important one, its forms of counteracting this phenomenon are very superficial. This is because they are mainly limited to housing maintenance costs. Moreover, the aid instruments used are, to a large extent, insufficient in the long term.
The results of the survey clearly indicate that in the local energy policy of the municipality, the Local Government talks about the possibilities or even the need to reduce energy demand, however, the instruments used by them are not very effective in the fight against heat energy poverty. This points to the need for a more detailed research programme and the development of a specific recovery and assistance programme, which will be addressed to the residents of households.

The authors hope that the subject will constitute a pragmatic basis for developing a strategic policy that will be applicable by Local Government Units in the country. This policy can effectively help in tackling the complex problem of poverty of household heat energy in the dimension of local communities.

\section{Acknowledgement}

The authors would like to thank the power plants to local self-government units for allowing them to carry out research on their premises. The authors also thank Ms. Mariola Nawrocka - the Head of the Scientific Information Center of the Military University of Technology in Warsaw for friendly and scientific cooperation.

\section{References}

1. Bakirtas, T. and Gokce Akpolat, A. (2018) 'The relationship between energy consumption, urbanization, and economic growth in new emerging-market countries,' Energy, 147, 110-121.

2. Bordman, B. (2012) 'Fuel poverty synthesis: Lessons learnt, actions needed,' Energy Policy, 49, 143-148.

3. Bouzarowski, S. (2018), "Energy poverty,' Palgrave macmillan. (eBook) [Online], [Retrieved January 22, 2019],

Katarzyna ŚWIERSZCZ, Tadeusz SZCZUREK, Szymon MITKOW, Jerzy ZALEWSKI and Bogdan ĆWIK (2019), Journal of Eastern Europe Research in Business and Economics,

DOI: $10.5171 / 2019.780276$ 
https://doi.org/10.1007/978-3-319-

69299-9, ISBN 978-3-319-69299-9.

4. Bouzarovski, S. and Petrova S. (2015) 'A global perspective on domestic energy deprivation: Overcoming the energy poverty-fuel poverty binary,' Energy Research \& Social Science, 10, 31-40.

5. Crémieux, M. (2014), "Propositions pour renforcer la lutte contre la précarité énergétique,' Terra Nova. [Online], [Retrieved January 22, 2019], http://tnova.fr/

6. Energooszczędność: współczesne wyzwania dla miast, (2014), [Online], [Retrieved January 22, 2019], https://www.google.com

7. Hilbert, A. and Werner, M. (2016) 'Turn up the heat! Contesting energy poverty in Buffalo,' NY. Geoforum, 74, 222-232.

8. Howard, R. (2015), "Warmer Homes: Improving fuel poverty and energy efficiency policy in the UK. Report by Policy Exchange,' [Online], [Retrieved January 22, 2019], http://www.policyexchange.org.uk, ISBN: 978-1-907689-89-5.

9. “International Energy Agency (IEA),' [Online], [Retrieved January 22, 2019], https://www.iea.org

10.Mirjana, R., Sanja, F. and Dejan P. (2015), 'Energy security measurement A sustainable approach,' Renewable and Sustainable Energy Reviews, 68, 10201032.

11.Owczarek, D. and Miazga, A. (2015) Ubóstwo energetyczne w Polsce definicja i charakterystyka społeczna grupy, Instytut na Rzecz Ekorozwoju, Warszawa.

12.Petrova, E. (2016), Leadership Theories In the Modern Security
Management, University of Information Technology and Management, Science Journal Security Review, 1, 3-13.

13.Pey, S and Dobbins, A. (2015), 'Energy poverty and vulnerable consumers in the energy sector across the EU: analysis of policies and measures,' Policy Raport, 2, 227-244.

14.Polish Energy Policy until 2030 (2009), Ministry of Economy, Warsaw.

15.Polish Energy Policy Project until 2050 (2014), Ministry of Economy, Warsaw.

16. Roberts, S. (2008), 'Energy, equity and the future of the fuel poor,' Energy Policy, 36, 4471-4474.

17.Rutkowski, J., Sałach K., Szpor A., and Ziółkowska K. (2018), Jak ograniczyć skalę ubóstwa energetycznego w Polsce?, IBS Policy Paper 1, Warszawa.

18.Sánchez-Guevara Sánchez, C., Mavrogianni, A. and Neila González, F. J. (2017), 'On the minimal thermal habitability conditions in low income dwellings in Spain for a new definition of fuel poverty,' Building and Environment, 114, 344-356.

19.Scarpellini, S., Sanz Hernández, M. A., Llera-Sastresa, E., Aranda, J. A. and López Rodríguez, M. E., (2017), 'The mediating role of social workers in the implementation of regional policies targeting energy poverty,' Energy Policy, 106, 367375.

20.Soroka, P. (2015), Bezpieczeństwo energetyczne - między teorią a praktyką, Elipsa, Warsaw.

21.Stępniak, A. and Tomaszewska, A. (2014) Ubóstwo energetyczne a efektywność energetyczna, Instytut na rzecz Ekorozwoju, Warszawa.

Katarzyna ŚWIERSZCZ, Tadeusz SZCZUREK, Szymon MITKOW, Jerzy ZALEWSKI and Bogdan ĆWIK (2019), Journal of Eastern Europe Research in Business and Economics,

DOI: $10.5171 / 2019.780276$ 
22.Szczurek, T. and Bryczek-Wróbel, P. (2017), Security of Large Urban Centres, In: Internal Security, Published by the Police Academy in Szczytno, 61-79. DOI 10.5604/01.3001.0012.1703.

23.Szpor A. and Lis M. (2016), Ograniczanie ubóstwa energetycznego $\mathrm{w}$ Polsce - od teorii do praktyki, IBS, Warszawa.

24.Świerszcz, K. (2016a) Bezpieczeństwo energetyczne Polski - wybrane aspekty obronne, Energetyka - szanse, wyzwania i zagrożenia. Logistyka - ekonomia prawo - polityka - bezpieczeństwo obronność - technika, Ćwik, B., Kwiatkiewicz, P. and Szczerbkowski, R. (ed), Fundacja na rzecz Czystej Energetyki, Poznań.

25.Świerszcz, K. (2018a), Energia geotermalna jako alternatywny zasób przeciwdziałania niskiej emisji w strategii bezpieczeństwa ekologicznego, Wyzwania i zagrożenia bezpieczeństwa i obronności w XXI wieku, w wymiarze społecznym i technologiczno-środowiskowym, Trejnis, Z. and Kościelecki, L. (ed.), ASPRA-JR, Warszawa.

26.Świerszcz, K. (2017), 'The Impact of Energy Poverty on the Level of Social Security' Proceedings of the 4th International Conference on Management Science and Management Innovation (MSMI 2017), ISBN: 978-94-6252-369-2, 23-25 Jun 2017, Suzhou, China, 175-178.

27.Świerszcz, K. (2019a) Postrzeganie bezpieczeństwa energetycznego $\mathrm{w}$ kontekście przeciwdziałania ubóstwu energetycznemu społeczności lokalnej $\mathrm{z}$ wykorzystaniem zasobów geotermalnych na terenie Gminy Wiśniowa, WAT, Warszawa.

28.Świerszcz, K. (2016b) 'Obrona bezpieczeństwa energetycznego Polski w
aspekci geotermalnych dóbr narodowych,' Przedsiębiorczość $i$ Zarządzanie, 17(5), 197-208.

29.Świerszcz, K. (2018b), Znaczenie geotermii $\mathrm{w}$ strategii bezpieczeństwa energetycznego na przykładzie poszczególnych regionów Polski, Dylematy współczesnej obronności i bezpieczeństwa państwa. Aspekty ekonomiczno-społeczne, Stańczyk, K. and Chyrzyński, R. (ed), Adam Marszałek, Toruń, 115-139.

30.Świerszcz, K. and Ćwik, B. (2017) 'Geothermal energy as a Part of Nonmilitary Defence Strategy in the Context of the Prevention of Energy Poverty of Local Communities,' Przedsiębiorczość i Zarzadzanie, 18(5),135-50.

31.Świerszcz, K. and Grenda, B. (2018a), Geothermal Energy as an Alternative Source and a Countermeasure Against Low Emission in the Ecological Security Strategy, Proceedings of the 2018 Joint International Conference on Energy, Ecology and Environment (ICEEE 2018), ISBN: 978-1-60595-590-2; ISSN: 24758833, 21-25 November 2018, Melbourne, Australia, 1-6.

32.Świerszcz, K. and Grenda, B. (2018b) 'Poziom ubóstwa energetycznego w wybranych regionach kraju jako miernik poziomu bezpieczeństwa energetycznego w wymiarze społecznym,' Przedsiębiorczość i Zarzq̨dzanie, 19(2), 211-30.

33.Świerszcz, K. and Osial, M. (2019b), Ubóstwo energetyczne a zasoby geotermalne $\mathrm{w}$ strategii bezpieczeństwa energetycznego kraju, Współczesne problemy zarządzania i bezpieczeństwa, Runiewicz, R., Żylińska, J., Szczerbak, M., Przychocka, I. and Gawkowski, K. (ed), UTH, Warszawa, 259-284.

Katarzyna ŚWIERSZCZ, Tadeusz SZCZUREK, Szymon MITKOW, Jerzy ZALEWSKI and Bogdan ĆWIK (2019), Journal of Eastern Europe Research in Business and Economics,

DOI: $10.5171 / 2019.780276$ 
34.Teller-Elsberg, J., Sovacool, B., Smith, T., and Laine, E. (2016) 'Fuel poverty, excess winter deaths, and energy costs in Vermont: Burdensome for whom?' Energy Policy, 90, 81-91.

35.Yergin D. (2006) 'Ensuring energy security,' Foreign Affairs, 85(2), 69-78.

36.Włodarczyk, E. (2018), Edukacja dla bezpieczeństwa, Vademecum bezpieczeństwa, Wasiuta, O., Klepka, R. and Kopeć, R. (ed.), Libron, Kraków.
37.Włodarczyk, E. (2018), Zarządzanie partycypacyjne bezpieczeństwem, Vademecum bezpieczeństwa, Wasiuta, 0., Klepka, R. and Kopeć, R. (ed.), Libron, Kraków. (ISBN: 978-83-65705-83-9).

38.Zalewski, J. (2015) ‘Wpływ policyjnego zarządzania biedą na bezpieczeństwo socjalne. Utopia neoliberalnej technologii kształtowania zachowań społecznych,' Studia Bezpieczeństwa Narodowego (National Security Studies) WAT, 8, 167181.

Katarzyna ŚWIERSZCZ, Tadeusz SZCZUREK, Szymon MITKOW, Jerzy ZALEWSKI and Bogdan ĆWIK (2019), Journal of Eastern Europe Research in Business and Economics, 